\title{
Commentary
}

\section{Covid-19 Misinformation and the Social (Media) Amplification of Risk: A Vietnamese Perspective}

\author{
Hoa Nguyen ${ }^{1, *}$ and An Nguyen ${ }^{2}$ \\ ${ }^{1}$ Philip Merrill College of Journalism, University of Maryland, College Park, MD 20742, USA; E-Mail: hnguyen7@umd.edu \\ 2 Department of Communication and Journalism, Bournemouth University, Poole, BH12 5BB, UK; \\ E-Mail: anguyen@bournemouth.ac.uk \\ * Corresponding author
}

Submitted: 3 May 2020 | Accepted: 5 May 2020 | Published: 26 June 2020

\begin{abstract}
The amplification of Coronavirus risk on social media sees Vietnam falling volatile to a chaotic sphere of mis/disinformation and incivility, which instigates a movement to counter its effects on public anxiety and fear. Benign or malign, these civil forces generate a huge public pressure to keep the one-party system on toes, forcing it to be unusually transparent in responding to public concerns.
\end{abstract}

\section{Keywords}

Covid-19 infodemic; disinformation; misinformation; online incivility; risk amplification; Vietnamese social media

\section{Issue}

This commentary is part of the issue "Health and Science Controversies in the Digital World: News, Mis/Disinformation and Public Engagement" edited by An Nguyen (Bournemouth University, UK) and Daniel Catalan (University Carlos III of Madrid, Spain).

(C) 2020 by the authors; licensee Cogitatio (Lisbon, Portugal). This article is licensed under a Creative Commons Attribution 4.0 International License (CC BY).

\section{Introduction}

Friday, the 6th of March, 2020 was a critical turning point in Vietnam's battle against coronavirus. A midnight press conference was called after a residence street in the centre of Hanoi was locked down. A few days before that, a young resident in this area returned from London, failing to declare to airport quarantine officers that she had been terribly unwell. She had now tested positive and become Vietnam's 17th Covid-19 patient. It was a brutal blow: The country had done its best to contain the virus from Day 1 and had seen no new case for 24 days. Flashing back to January, when coronavirus started to wreak havoc in Wuhan, Vietnam's top leadership, disregarding all assurances from the Chinese government, its traditional political frenemy, was quick to take heavy-handed measures-including closing its 900-mile land border with China, ordering schools not to reopen after the Lunar New Year, and deploying its extensive surveillance system to track and trace primary, secondary and tertiary contacts of patients. By midFebruary, things seemed to have eased off, with the number of cases staying unchanged from the 12th onwards. Until now.

The midnight press conference led many Vietnamese into a white night of hysteria and then days of panics. With that came an extreme level of incivility on social media. In the hours following the news, Patient 17 became a target of brutal online attacks, especially on Facebook, with a staggering amount of hate speech against her. Unsubstantiated information about her whereabouts in Europe before returning to Vietnam was, intentionally or unintentionally, spread on Facebook, as were intimate images and details about her seemingly prodigal lifestyle and decadent personality. A Facebook page named Patient 17 was created for people to post information about the "rich kid" and voice anger towards her. Some labelled her a national traitor and called for her to be criminally prosecuted for being dishonest about her health at the airport, which for them was the root of this 
new saga. A few even wanted to kill her. Some of the domestic media and expatriates' news sites were quick to join the crowd, creating a chaotic world where human dignity -in this case, that of a hospitalized patient battling for life-was relentlessly stampeded in temper.

Incivility is nothing unfamiliar on Vietnamese social media. A week before the above incident, Microsoft (2020) published a Digital Civility Index report, ranking Vietnam at the 21th out of 25 surveyed countries, mainly because of the pervasive risks that its digital media pose to professional reputation, personal safety, and health and wellbeing. Among the oft-mentioned problems are unwanted contacts, sex-related offences, hate speech, and the spread of fake news, hoaxes, and scams. Disrupting Vietnamese life in that context, Covid-19 seems poised to cause incidents such as the above. This commentary will examine this social media phenomenon through the theoretical lens of social amplification of risk.

\section{A Vicious Circle}

The central assumption of social amplification theory is that events pertaining to hazards 'interact with psychological, social, institutional, and cultural aspects in ways that can heighten or attenuate public perceptions of risk and shape risk behaviors' (Renn, 1991, p. 287). Social amplification happens in two stages: The risk is first amplified during the transfer of information, triggering social responses that in turn, further amplify the risk (Renn, Burns, Kasperson, Kasperson, \& Slovic, 1992). As hazardous events, especially those with a close proximity to a community (Costa-Font, 2020), interact with individual psyches and socio-cultural factors-such as the intensity of public reactions on social networksthey create ample room for miscommunication about related risks (Busby \& Onggo, 2013). Given the unforeseeable and uncontrollable aspects surrounding hazardous events, even minor hiccups in the process of relaying legitimate, fact-based information can trigger a strong public response and/or result in detrimental impacts on society and the economy.

This social phenomenon manifests in the informational chaos that coronavirus creates in Vietnam's social media. Like other outbreaks, it is associated with a great deal of uncertainty. Ironically, as science and other authorities know the least about the novel virus, the public thirst for answers is at the highest point. For Vietnamese, this was asymmetry at the extreme. The risk is perceived to be at the doorstep since Vietnam has strong physical, economic, and political connections with China, a country that the Vietnamese public-often at odds with its leadership's ambivalent relationship with its Chinese communist counterpart-holds a strong sentiment against. This, aided by a general lack of trust in government transparency and confusing responses by public authorities in the early stage of the outbreak, led people to have nowhere to satisfy their need to know but their own interpersonal networks. Simply put, when rushing for answers without receiving any from authoritative sources such as scientists, health professionals, and government bodies, people turn to any source they trust in daily life, even though those sources are in no better position to know more about the disease.

Such amplification is seen in any disease outbreak, but things would have been a little more manageable in the past. During the H1N1 pandemic (2009-2010), for instance, gossips about the outbreak were restricted to smaller settings, such as a beer/coffee catch-up, a phone chat, a community meeting, a family reunion, or at best, the less interactive and less personal online spaces like blogs, forums or the then nascent Facebook. 2020 was, however, different: Vietnam now had 68 million Internet users, with 65 million being active on social media (Hootsuite \& We Are Social, 2019). Amidst the vast uncertainty, Facebook quickly became a main place for Vietnamese to seek, share, and discuss news and information about Covid-19 as a way to deal with their growing uneasiness and impatience. By allowing users to get news and information from not only friends but "friends of friends" or even "friends of friends of friends," social media create a fertile land for pandemic rumours, fake news, hoaxes and so on-especially those appealing directly to negative emotions such as anxiety and fear-to grow at an exponential rate.

Overall, as we have reviewed elsewhere (Nguyen, 2020), the Covid-19 infodemic on Vietnamese social media features three major types of mis/disinformation. The first is false information and conspiracy theories about the origin of the virus - such as that Coronavirus is a biological weapon being leaked from a lab in Wuhan, that Coronavirus is an attempt to make money by the big pharma, that coronavirus is an effort by the rich and powerful to reduce global population growth. Most of this was translated from foreign sources by either social media users or some gullible mainstream news outlets.

The second surrounds the development of the pandemic. This can take the form of deliberate make-believe posts-such as a translated video of a fake Wuhan health worker claiming in January that hundreds of thousands were infected with the virus, not thousands as the Chinese government said. Sometimes, it might be just rudimentary posts declaring something without any supporting evidence-e.g., someone has died of the virus somewhere. Such crude mis/disinformation could find its way through the net simply because it is the daily obsession of a worried public.

The third is around prevention and treatment measures: While scientists are yet to understand the virus and its working mechanisms, a plenitude of "health advice" has been posted online to teach people how to kill it or even to treat Covid-19. The most shuddering is advice for people to drink their own urine or bleach to prevent, even treat, Covid-19. Less severe are the numerous posts claiming people can stay away from Coronavirus by sunbathing, drinking hot water, avoiding ice creams, using 
hair driers, wearing a face mask soaked with saline solution, or eating garlic, pepper, ginger, kimchi and so on.

To be sure, some mis/disinformation has stealthy intent behind it. There are, for example, the invisible hands of hackers and state apparatuses who spread false and malicious content about the Covid-19 to exploit public fear for personal, commercial or political gains. In most cases, however, it is likely that the information chaos is down to a combination of negative emotions and low media literacy: People, out of fear/anxiety and the lack of news evaluation skills, unwittingly like and share wrong or untruthful information in their genuine but hasty belief that it is true. In February, soon after a woman died at a hospital in Ho Chi Minh City, her death declaration, personal identity, and close-up photos were immediately circulated on Facebook and other social platforms. The "news" was that she died of Coronavirus. The death note, however, specifies clearly that her death was caused by 'myocarditis, multiple organ dysfunction' (quoted in Nguyen, 2020). It was the few extra caution words after that-'flu not excluded' - that sparked the rumour. It was easily taken as truth by many people who, in their sincere intention to alert others, did not pause to question the information or read the death note.

In short, from the perspective of social amplification theory, Covid-19 on Vietnamese social networks could be a classic example of risk being amplified in a vicious circle of intensified and attenuated signals about itself. The more information people seek on social media, the more confusion many-if not most-seem to have. As confusion goes that direction, it reaches a point when information quality becomes secondary to bias confirmation. As social messaging around Coronavirus is amplified to deaf ears, it contributes considerably to the formation and consolidation of anxiety and fear. Its effects can be seen in a range of irrational behaviours in real life: stockpiling food, queuing from 4 am to buy facemasks, abusing rumoured Covid-19 cures (e.g., chloroquine), discriminating people from areas with Covid-19 cases (e.g., Vinh Phuc province), and so on.

\section{The Bright Side}

Not everything is bleak, however. The chaos has seen many troubled users trying to do their bit, either as individuals or as group members, to mitigate its dreadful impacts. A voluntary Facebook page called News Check (Kiểm Tin) has been proactive in exposing fake Covid-19 news. By the end of April, less than five months since its birth, the page had about 24,000 followers, having published more than 260 posts that fact-check, cross-verify and debunk fabricated stories or false claims on both mainstream and social media. On YouTube, there is a boom of clips warning people of the emerging infodemic. Many KOLs (Key Opinion Leaders) support the fight by voicing their views about false claims, helping bring the "infodemic" concept into Vietnamese households. Some doctors, epidemiologists and journalists have become es- sential Facebook places for confused members of the public to check for authoritative news and advice.

In the absence of systematic research, however, it is impossible to know the extent to which such efforts have changed the hearts and minds of a panicked public. Like other bad news, misleading or untruthful content around Covid-19 sweeps through the network with a much faster speed and wider reach than any correction. Further, those with the good intention to fix things are still a minority compared with the millions of emotionally driven Facebook users. While social media companies have been proactive in cleaning their space, their efforts seem to focus on clear fabrications, with insufficient attention to the subtle, probably more popular type of factually correct but substantially untrue content (e.g., correct facts that are "massaged" or misinterpreted during sharing or commenting).

The amplification of Covid-19 risk through mis/disinformation on social media, however, does seem to have an unexpected positive effect: It creates immense pressures on the one-party regime, forcing it to go out of its usual secrecy to address public concerns. After an initial period of disconcerted responses, Vietnamese authorities realised the urgent need to unite words and actions, sparing no effort to control the flow of information in parallel with its extensive track-andtrace system. There have been controversial movessuch as a new decree that has since February led about 800 people to be heavily fined (at amounts equivalent to three to six months of basic salaries) for spreading mis/disinformation about Covid-19 (Reed, 2020). But, under intensive public scrutiny, there has been an unexpected level of transparency and creativity. Every new Covid-19 case, with details about their movements and contacts, is immediately published on governmental websites, mainstream media, and social media. Different forms of media, such as outdoor posters, television trailers, and even dancing performances, are used to keep people abreast of developments as well as to understand the virus, its transmission and its prevention measures. In February, Coronavirus Song (Ghen Cô Vy) -a Ministry of Health's edutainment clip to mobilise people to fight the virus-went viral on YouTube (with 4.4 million views as of April 30), made news on global news channels and websites and has since been translated and mutated in other countries.

As we write, Vietnam has started to return to normal life, being internationally acclaimed for its resolute, lowcost response to Covid-19. If this sustains as a success throughout the rest of the pandemic, future historians will have one sure thing to say: the strangely joined force of the good, the bad and the ugly on Vietnam's social media was part of that success.

\section{Conflict of Interests}

The authors declare no conflict of interests. 


\section{References}

Busby, J., \& Onggo, S. (2013). Managing the social amplification of risk: A simulation of interacting actors. Journal of the Operational Research Society, 64(5), 638-653.

Costa-Font, J. (2020). Dealing with Covid-19 requires pre-emptive action to realistically communicate risks to the public. Impact of Social Sciences. Retrieved from https://blogs.lse.ac.uk/impactofsocialsciences/ 2020/03/25/dealing-with-covid-19-requires-preemptive-action-to-realistically-communicate-risksto-the-public

Hootsuite, \& We Are Social. (2019). Digital 2019: Global digital overview. Retrieved from https:// datareportal.com/reports/digital-2019-globaldigital-overview

Microsoft. (2020). Vietnam digital civility index 2020. Redmond, WA: Microsoft. Retrieved from https:// news.microsoft.com/wp-
content/uploads/prod/sites/421/2020/02/DigitalCivility-2020-Global-Report.pdf

Nguyen, A. (2020, March 10). Mạng xã hội Việt Nam, những ngày nóng dịch [Vietnamese social media, the hot days of the pandemic]. BBC Vietnamese. Retrieved from https://www.bbc.com/vietnamese/ forum-51820861

Reed, J. (2020). Vietnam's Coronavirus offensive wins praise for low-cost model. Financial Times. Retrieved from https://www.ft.com/content/0cc3c956-6cb211ea-89df-41bea055720b

Renn, O. (1991). Risk communication and the social amplification of risk. In R. E. Kasperson \& P. J. M. Stallen (Eds.), Communicating risks to the public (pp. 287-324). Berlin: Springer.

Renn, O., Burns, W. J., Kasperson, J. X., Kasperson, R. E., \& Slovic, P. (1992). The social amplification of risk: Theoretical foundations and empirical applications. Journal of Social Issues, 48(4), 137-160.

\section{About the Authors}

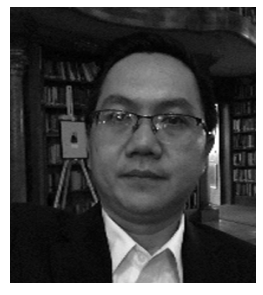

Hoa Nguyen is a PhD Candidate at Philip Merrill College of Journalism at the University of Maryland, where he also works as a Teaching Assistant in Media Literacy, Journalism Leadership, and Audience Metrics. He researches mainstream media versus digital media, audience metrics, risk communication, climate change in the news, media literacy and media history. His work also covers the power of journalism professionalism and education in the digital age. Before embarking on his PhD, he was Director of News at HTV (Ho Chi Minh City Television), one of Vietnam's major television networks.

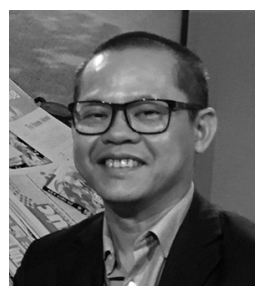

An Nguyen is Associate Professor of Journalism in the Department of Communication and Journalism, Bournemouth University, UK. He has published widely in several areas: digital journalism, news consumption and citizenship, citizen journalism, science journalism in the post-truth era, data and statistics in the news, and news and global developments. His work has appeared in, among others, Journalism, Journalism Studies, Journalism Practice, Digital Journalism, Public Understanding of Science, International Journal of Media and Culture Politics, Information Research, Journal of Sociology, and First Monday. Prior to academia, he was a science journalist in Vietnam. 